\title{
"Make Sioux City \\ a Good Place to Live"
}

Organizing Teamsters in Sioux City, 1933-1938

\section{ERLING N. SANNES}

SIOUX CITY BOOSTERS boasted in 1930 that "the high type of workmen found in Sioux City industries do not readily lend themselves to labor agitation, and as a whole Sioux City has been free from labor trouble."1 As usual, the boosters exaggerated. Yet union organizers up until that time had faced formidable obstacles in Sioux City. Several attempts to organize Teamsters locals, for example, had faltered after flourishing briefly. On August 3, 1933, however, the International Brotherhood of Teamsters chartered Sioux City Local 383. By the end of the decade it had evolved into an effective bargaining unit.

A combination of factors and incidents account for the union's emergence as an effective agent in the 1930s. Union activists took advantage of national depression-era legislation to organize unions and recruit workers from a wide range of trades and industries. Also in the 1930s regional labor organi-

An earlier version of this article was presented at the Missouri Valley History Conference, 11 March 1988.

1. Thomas P. Christensen, "An Industrial History of Woodbury County," serialized in Unionist and Public Forum, Labor Day edition, n.d., 1940. A few years earlier Sioux City's labor paper, The Advocate, had hailed Sioux City as a "laboring man's town-one of the best cities in the world for the laboring man." Quoted in William H. Cumberland, Wallace M. Short: Iowa Rebel (Ames, 1983), 48.

THE ANNALS OF IOWA 50 (Fall 1989/Winter 1990). CThe State Historical Society of lowa, 1989. 
zations emerged to consolidate power and to lend support to local organizing efforts. As an important regional center for Iowa and the surrounding states, Sioux City benefited from and contributed to those regional efforts. Finally, though, successful union organizing depends on a consciousness among workers that solidarity breeds success.

After several years of frustration while Teamsters Local 383 tried to organize Sioux City coal drivers, four incidents in 1937 and 1938 contributed to a new sense of solidarity among Sioux City workers: a strike and boycott against the Voss Cafe, which first revealed to Local 383 the power of worker solidarity; a conflict with a building contractor and the Sioux City Master Builders Association, which strengthened the Sioux City Building and Trades Council; cooperation with the North Central Area Negotiating Committee in an action against Holdcroft Transportation Company, which showed the benefits of solidarity throughout the region; and a thirty-day strike by bakery workers and drivers, which proved to be a key turning point for the history of the labor movement in Sioux City. Through these incidents Sioux City workers learned the value of building solidarity across trades and actively cultivating community support. Sioux City's rich heritage of labor politics made a significant contribution to this latter effort.

SIOUX CITY, with a population of 47,828 , had become the second largest city in the state by 1910 . It continued to grow over the next two decades. By 1930 the population had reached 79,183 , and was notable in lowa for its social, ethnic, and racial diversity: 30,190 (38 percent) of its residents in 1930 were of foreign parentage or were themselves foreign born; 1,064 (1.3 percent) were black; and 182 of Iowa's 660 native Americans lived in Sioux City. The city's rapid growth was due largely to its function as an important regional marketing center for an area that included not only northwestern lowa but extended as far west as Montana and Wyoming. In 1930, when 60 percent of Iowa's population was rural, its economy was dominated by agriculture; Sioux City's location at the junction of Iowa and the even more rural states of Nebraska and South Dakota made it 
even more dependent on agriculture than other urban centers in Iowa. ${ }^{2}$

Sioux City was most important as a livestock marketing and meatpacking center; more than one-third of the persons employed in manufacturing in Sioux City were employed in the packing plants. Other industries drawing on the region's agricultural economy were also significant, however. At the beginning of the 1930s there were ten bakeries in Sioux City-Continental Baking was the largest bakery in Iowaand its creameries were among the largest in the United States. Sioux City boosters were always ready to boast that their city was one of the most important commercial centers in the country. ${ }^{3}$

Despite the claims of its boosters, Sioux City had a rich labor history even before the 1930s. In 1904 there were more than fifty labor unions-including Teamsters Local 389 with 210 members - a labor press, and a determined cadre of labor leaders in Sioux City. ${ }^{4}$ In 1902, however, Sioux City businessmen had organized the Sioux City Industrial Association. In its efforts to promote a favorable business climate for attracting new businesses to Sioux City, it gave close attention to the labor movement. Then in 1904 the Cudahy packing plant succeeded in breaking a long, bitter strike, and it replaced most of its work force with new immigrants who were willing to work at wages offered by the packers. For more than a decade after the 1904 strike, there were no serious labor conflicts in Sioux City. In 1908 the Industrial Association began to promote an open shop policy, which crushed

2. U.S. Department of Commerce, Bureau of the Census, Fifteenth Census of the United States, 1930: Population Bulletin, Second Series, Iowa (Washington, DC, 1931), 43-46, 75; U.S. Department of Commerce, Bureau of the Census, Fifteenth Census of the United States, 1930: Population, vol. 1, Number and Distribution of Inhabitants (Washington, DC, 1931), 361-63.

3. U.S. Department of Commerce, Bureau of the Census, Fifteenth Census of the United States, 1930: Population, vol. 4, Occupations by States (Washington, DC, 1933), 528, 534; Christensen, "Industrial History," in Unionist and Public Forum, 14, 29 February 1940; Cumberland, Wallace Short, 47.

4. Christensen, "Industrial History," in Unionist and Public Forum, 1 August 1940; Iowa State Federation of Labor, Official Labor Gazette and Directory, 1901 (Des Moines, 1903), 21-23. 
many of the unions that did manage to organize during this period, including Teamsters Local $389 .{ }^{5}$

Due to the increased demand for labor during World War I, Sioux City employers eased their open shop position, and labor conditions improved. By 1918 some four thousand Sioux City workers, about one-fourth of the work force, were organized in more than fifty unions. ${ }^{6}$ The agricultural depression of the 1920s followed by the Great Depression of the 1930s had a devastating impact on Sioux City workers, however. ${ }^{7}$ Like many other places throughout the United States, Sioux City reinstated its open shop policy in the 1920s, but the speed and vengeance with which it was applied there was at least in part the business community's way of retaliating for labor's support of the labor government of Mayor Wallace Short, who administered the city government from 1918 to $1924 .^{8}$

By 1930 few unions remained in Sioux City, and most of them were small, exclusive unions of skilled trade and craftsmen, such as musicians, cigar makers, movie operators, stage hands, typographical unionists, and others who had little interest in leading a mass organization of unskilled or semiskilled workers, to say nothing of the masses of unemployed created by the Great Depression. Workers in Sioux City, as elsewhere,

5. Christensen, "Industrial History," in Unionist and Public Forum, 1, 8 August, 12 September 1940; Iowa State Federation of Labor, Official Labor Directory, 1914, and Proceedings of the Twenty-Second Annual Convention of the Iowa State Federation of Labor Held at Davenport, June 9-12, 1914, 15.

6. Union Advocate (Sioux City), 29 August 1918; Christensen, "Industrial History," in Unionist and Public Forum, 1, 15 August 1940.

7. Scott Alan Sorensen, "Law Enforcement During the 1930's in Sioux City, Iowa" (M.A. thesis, University of South Dakota, 1976), 16-17.

8. Unionist and Public Forum, 3 December 1936; Sioux City Journal, 16 April 1920. Iowa has had a rich history of electing members of organized labor or labor-backed candidates to municipal offices, but the 1918 Sioux City election is significant because it was the first time an entire slate of candidates running on a labor ticket had been elected under a commission form of government in Iowa. For accounts of victories in municipal elections in Iowa by candidates supported by Knights of Labor and Socialists, respectively, see Ralph Scharnau, "Workers and Politics: The Knights of Labor in Dubuque, Iowa, 1885-1890," Annals of Iowa (Winter/Spring 1987), 353-77; and William H. Cumberland, "The Red Flag Comes to lowa," Annals of Iowa (Fall 1968), 441-55. 
were forced to improvise a variety of forms of direct action to improve their lot. ${ }^{9}$

The Sioux City Unemployed Council, like organizations of the unemployed that had sprung up in various locations around the country, worked to prevent evictions, stop foreclosures, agitate for relief assistance, and demand work for the unemployed. It attracted a large membership and led or partici-

9. Sioux City received national notoriety in a July 22, 1933 article in Liberty, "The Fight on the Farm Front," which said, "It was in 1775, at Lexington, Massachusetts, that the embattled farmers fired the first shots of the first American Revolution. It was at Sioux City, lowa, that the embattled farmers of 1932 started the second one. Farm strikes, milk strikes, anti-foreclosure mobs and 'penny auctions,' threats to lynch the judiciary, organized resistance to taxes and evictions began in lowa, the most conservative and most thoroughly American state in the union, and have spread from there like a prairie fire. Hats off to Iowa! No red-blooded American can blame the farmers for refusing to be run off their lands and sent to the bread lines." In an editorial in the Unionist and Public Forum, 20 July 1933, which cited the Liberty article, Harold Sturgeon wrote, "Right here let us state that if Sioux City shall go down in history as having played any part whatsoever in the progress of social and economic betterment-a part already recognized by writers of national reputation-it will be because of the activities of these farmers, and perhaps of the workers of Sioux City, who are now making a brave fight against a system of abject slavery and in behalf of decency and fair play for those workers who have been unfortunately caught in the meshes of a manmade depression."

Little is known about the involvement of Sioux City workers in the farm revolt, but of the ninety pickets arrested during the August 1932 strike, seven were Sioux City trade unionists. See Unionist and Public Forum, 9 April 1936. This is an area that deserves more study along with the other aspects of the farm revolt recently identified by William C. Pratt, "Rethinking the Farm Revolt of the 1930's," Great Plains Quarterly (Summer 1988), 131-44.

Milk-wagon drivers were inspired to start a Teamsters local as a result of their participation in a Farmers' Holiday Association demonstration during September 1932. One of the charter members of the union, a dairy worker, recalled that Sioux City dairy workers decided to organize after parading farmers responded to shouts of support, saying, "If you strike, we'll feed you." Ed Turk, interview with author, 21 January 1988. See also Lement Harris, My Tale of Two Worlds (New York, 1986), 145. The Sioux City dairies and creameries refused to negotiate with the union, and a number of drivers and inside workers were fired for joining the union. Despite appeals by the Unionist and Public Forum for Sioux City residents to buy their milk only from deliverymen who carried a union card, the union was not able to gain a foothold in Sioux City. See Unionist and Public Forum, 17 May 1934. By 1935 the workers had become discouraged and demoralized, and membership had declined to fewer than fifteen members. By 1936 the union ceased to exist. See MSS 9 Teamsters (John Geary, 1935-37), series 1, box 29, State Historical Society of Wisconsin, Madison, Wisconsin. 
pated in a number of strikes, marches, protests, demonstrations, and social gatherings that helped to raise the consciousness of Sioux City workers, to give them a renewed sense of their collective power and a determination to organize unions. ${ }^{10}$

On June 16, 1933, Congress, in a special session, passed the National Industrial Recovery Act (NIRA). Sioux City employers responded enthusiastically to the features of the bill that they expected to stimulate industrial recovery. On August 16 hundreds of Sioux City employers and other NRA supporters held the first civic NRA parade and demonstration in the United States. More than fifty thousand spectators lined the streets to view a three-mile line of floats and motor vehicles that took more than two hours to pass the reviewing stand. Later fifteen thousand employers and workers sat side-by-side in Grandview Park to hear Iowa Congressman Guy M. Gillette urge everyone to buy only where "you see the Blue Eagle."

10. The Sioux City Unemployed Council was by no means unique. Throughout the United States in the 1930s unemployed workers organized a variety of organizations to meet their pressing needs. Nationally, the Communist party organized the Unemployed Councils, the Socialist party established the Workers Alliance, and the Communist League of America organized the Unemployed Leagues. See Sidney Lens, Left, Right, and Center: Conflicting Forces in American Labor (Hinsdale, IL, 1949), 258; David J. Leab, "'United We Eat': The Creation of the Unemployed Councils in 1930," Labor History (Fall 1967), 300-315; Roy Rosenzweig, "Socialism in Our Time': The Socialist Party and the Unemployed, 1929-1936," Labor History (Fall 1979), 485-509; and idem, 'Radicals and the Jobless': The Musteites and the Unemployed Leagues, 1932-1936," Labor History (Winter 1975), 52-77. In Sioux City the Communist party took the lead in organizing the unemployed. The impetus for organizing the Sioux City Unemployed Council may have come from Council Bluffs, which not only had a nine-member unit of the Communist party but also an active three-hundred-member Unemployed Council. See Daily Worker, 19 May, 11, 20, 23, 25 June 1931. Wallace Short, Harold Sturgeon, and the Reverend Gordon Kent were prominent in the efforts to organize the unemployed in the early 1930s, especially in the summer of 1933, when three thousand city and county relief workers struck for increased relief assistance. After twelve individuals were arrested and charged with criminal syndicalism during a police raid of a meeting organized by the Communist party in September 1933, Communist party efforts to organize the unemployed diminished. The void was filled, however, by Harold Sturgeon, who began an aggressive campaign to organize the Workers Alliance in Sioux City and elsewhere in northwestern Iowa. See Daily Worker, 13, 30 June 1931, 3, 16 March, 2 August 1932; Unionist and Public Forum, 12 July 1933; Sioux City Journal, 27 June, 6, 10, 13, 16, 20 July, 1, 19 August, 28 September, 5, 7, 26 October, 5 December 1933, 12 January 1934, 11 February 1934. 
Sioux City residents were proud that the Blue Eagle, national emblem of the NRA, had been designed by Frank R. Wilson, a native of Woodbury County, former publisher of the University of Iowa's Daily Iowan, and a former staff member of the Sioux City Journal. ${ }^{11}$

The employers' enthusiasm for the NIRA waned, however, when they saw thousands of Sioux City workers taking advantage of a provision of the act that "employees shall have the right to organize and bargain collectively through representatives of their own choosing, and shall be free from the interference, restraint or coercion of employers. ${ }^{12}$ Sioux City workers began pouring into existing unions and organizing new unions where none existed. Within one month after the act was signed into law, more than twelve hundred packinghouse workers, bakery workers, garment workers, restaurant employees, butchers, barbers, retail clerks, drivers, auto mechanics, and many others either had become members of existing unions or had organized new ones. By Labor Day there were more than three thousand new union members in the city. ${ }^{13}$

This great outpouring of workers took Sioux City employers by surprise. They quickly mounted a campaign to discourage union organizing: they pointed to the Blue Eagle, which they displayed at their place of business; they told workers it was unnecessary to organize because the government was going to establish wages, hours of work, and working conditions; and they refused to sign closed shop agreements with the unions of their workers. In October 1933 the Sioux City Chamber of Commerce issued its own interpretation of the NIRA, reminding its members that under the act "employees could bargain individually and not through organizations, if they so prefer," and insisting that closed shop agreements interfered with the workers' "right to bargain individually and would amount to employer coercion, which is against the law." In this context several groups of Sioux City workers attempted to

11. Sioux City Journal, 16, 17, 31 August, 3 September 1933.

12. Quoted in Irving Bernstein, Turbulent Years: $A$ History of the American Worker, 1933-1941 (Boston, 1970), 34.

13. Unionist and Public Forum, 8 June, 12 July, 26 October 1933. 
organize under the charter of the International Brotherhood of Teamsters. ${ }^{14}$

COAL DRIVERS were among those Sioux City workers who organized in the summer of 1933 . The organizational meeting on July 24, 1933, was well attended, but most of those present "were either out of work or out of money and most of those who were working were afraid of losing their job if their employer found out they had joined a union." But they were determined to organize. Officers were elected, and on August 3, 1933, the International Brotherhood of Teamsters chartered Chauffeurs, Teamsters \& Helpers, Local 383.15 The efforts of the coal drivers over the next five years illustrate the frustrations faced by workers who sought to organize unions during those years. Their experience also reflects the rhythms and character of union organizing in the wake of the shifting pattern of New Deal legislation.

The country was already in the fourth year of the Great Depression when Local 383 received its charter. Wages and working conditions in Sioux City had struck bottom. While the cost of living was on the increase, wages had not risen, and many workers subsisted on near starvation wages. Workers in the Sioux City coal yards earned as little as twelve dollars per week for forty-eight to eighty hours of work per week with no pay for overtime. There were no vacations, sick leave, or other benefits. Contract coal haulers who furnished their own trucks received thirty to seventy-five cents per ton of coal delivered. The work was seasonal; most coal-yard workers worked for only four or five months during the fall and winter. The odd jobs they performed during the spring and summer, when they could find them, paid even less. Sioux City coal-yard workers welcomed any opportunity to improve their wages and working conditions, and by January 1934, less than six months after the

14. Ibid., 27 July, 5, 7 September, 26 October 1933.

15. William Molden, recording secretary, Local 383, to Thomas L. Hughes, general secretary, International Brotherhood of Teamsters, Chauffeurs, Stablemen \& Helpers, 25 July 1933, Accounting Department, International Brotherhood of Teamsters, Washington, DC. 
Teamsters local had received its charter, membership in the union had grown to three hundred. ${ }^{16}$

In the winter of 1934 the Sioux City coal dealers adopted the NRA code, which established a thirty-five cent hourly wage and a forty-hour work week for Iowa coal-yard workers. Members of Local 383 felt strongly that the NRA wage scale was too low, so the union drew up its own demands for presentation to the operators. None of the coal yards would sign a contract with the union, but through negotiations and without resorting to a strike, the drivers did win a wage scale of fifty cents per hour for drivers, forty-five cents per hour for helpers, and from fifty cents to $\$ 1.20$ per ton, depending on the type of coal hauled, for the contract coal haulers. ${ }^{17}$

Each employer maintained that he had fought the other employers to get the wages increased. The union, they claimed, was unnecessary; it had nothing to do with obtaining the increased wage scale. This deception had a fair amount of success because many of the drivers were young and inexperienced. One by one they yielded to their employers' suggestion that they did not need the union any more and began to drop their membership in Local 383. Before long the ranks of the union had dwindled to only 121 members. ${ }^{18}$

A small cadre of drivers remained loyal to the union. They were unwilling to depend on the goodwill of the coal-yard operators and believed that only a union contract with the employer would bring real job security. When the union attempted to reorganize the drivers in a few selected coal yards, some of them came back to the union. The coal yards continued to resist any attempt by Local 383 to organize, however. Workers were threatened with the loss of their jobs if they joined the union; some were discharged when their employer found out they had joined Local 383; others were laid off without regard to seniority if there were indications they exhibited pro-union

16. Unionist and Public Forum, 11 January 1934, 9 November 1939; Roy Barr, interview with author, 21 January 1988. Though not a charter member of Local 383, Barr joined the union soon after its organization.

17. National Recovery Administration, Code of Fair Competition for the Retail Solid Industry, code Nr. 280 (Washington, DC, 1934), 3; Unionist and Public Forum, 9 November 1939.

18. MSS 9 Teamsters, series 1 , box 29 . 
sentiments; still others were given only part-time work; and a few were blacklisted by the coal yards. ${ }^{19}$

In the winter of 1935 Local 383 targeted the Watson Coal Company for organizational work. When one of the workers was fired for union activity, Local 383 launched a vigorous campaign to get the worker reinstated. The union organized a boycott and distributed handbills throughout the city proclaiming that the Watson Company was unfair to its workers. The Sioux City Trades and Labor Assembly passed a resolution branding the company as unfair. The boycott was so effective that Watson threatened to sign a contract with the union unless the rest of the coal yards would provide assistance. The other yards undoubtedly welcomed the increased business they received, but Watson's threat was of greater concern to them. As a result, the Sioux City Coal Dealers Association agreed to set up a committee to resolve the grievance with the union. The committee included three representatives from the industry and three from the union. A local judge was named chairman, but neither side would agree that the judge's finding would be final and binding. After hearing both sides, the judge wrote a report urging both sides to sit down and resolve their differences. But the Coal Dealers Association refused to negotiate with the union, which left matters as they were before. When Local 383 threatened to strike, the dealers warned that strikebreakers would be brought to Sioux City. Local 383 sent several appeals for assistance to the Minneapolis Regional Office of the National Labor Relations Board, but was informed that because of the press of affairs in Minneapolis and Fargo, North Dakota, no one could be spared to help the Sioux City workers. ${ }^{20}$

As the controversy wore on, the dealers met and decided that all of them would refuse to hire or permit continued employment of union members. Many of the companies began notifying their employees to discontinue their union membership or be fired. These threats had some effect, except in two coal yards where the union had a solid majority and where the

19. Unionist and Public Forum, 9 November 1939.

20. Ibid.; National Labor Relations Board, RG 25, Docket 240, Sioux City Coal Dealers, National Archives, Washington, DC. 
workers had the courage to defy their employers' demands and remain loyal to the union. But these courageous workers were dealt a severe blow when the United States Supreme Court declared the National Industrial Recovery Act unconstitutional in May 1935. The Sioux City coal yards began slashing wages, lengthening the hours of work, and discontinuing overtime pay. ${ }^{21}$

The Wagner Labor Relations Act, passed by Congress in July 1935, included provisions requiring employers to bargain with unions that represented a majority of employees, but still the Sioux City Coal Dealers Association refused to negotiate with Local 383 or permit the National Labor Relations Board to hold elections. In August 1937 Local 383 began an intensive campaign to reorganize, and hired Howard Fouts as a full-time organizer. Before long almost all of the coal drivers and helpers in the Sioux City coal yards joined the union under the slogan, "If we all stick together we'll win." 22

In early November 1937 the union mailed a proposed contract to the coal dealers with a request that the dealers meet with the union committee for negotiations. Not until they were faced with the threat of an industry-wide strike did the dealers agree to meet with the union. After several meetings, the parties arrived at a wage agreement providing for an hourly wage of fifty-five cents per hour for the first eight hours per day and time and one-half for all overtime work. Helpers and miscellaneous workers were to be paid fifty cents per hour. ${ }^{23}$

The employers refused to agree in writing to a seniority plan, sick leave, or vacations, or to recognize Local 383 as sole bargaining agent for the drivers. The dealers were determined to set the conditions of employment themselves. Seniority was particularly important to the union in the coal industry; without a provision for seniority and recall rights the dealers would not rehire union members when the coal season began in the fall. In lieu of contract provisions for seniority, sick leave, and vacations, the coal dealers offered to include in the contract a provision that "any local customs and conditions now prevail-

21. Unionist and Public Forum, 9 November 1939.

22. Ibid., 16 November 1939.

23. Ibid. 
ing in the various yards shall continue." The union was skeptical of such a provision, but nevertheless ratified the contract on December 6, 1937. ${ }^{24}$

The doubts of union members regarding the worth of such a gentlemen's agreement were soon vindicated when those coal yards that used contract drivers began holding up coal orders until later in the morning, forcing the drivers to sit around without work. Some yards hired more contract drivers than needed, which resulted in less work for the regular contract drivers; others discontinued paying Sunday and holiday pay to their hourly workers because they interpreted the "local customs" clause in the contract to have reference only to "the way the work is performed." Early in April 1938 the coal dealers notified the union that on May 6,1938, they would slash wages by 10 percent and discontinue overtime pay. Negotiations between the union and dealers continued for several months, but since the coal season was over and a majority of the workers had been laid off, the union had lost most of its leverage, so it decided to accept the wage scale offered by the dealers and press for a wage increase before the start of the coal season in the fall of 1938. By then, though, Local 383 was confronted with a lockout of its transfer drivers, and it yielded to the International Brotherhood of Teamsters recommendation to put off further attempts to organize the Sioux City coal industry until the fall of $1939 .{ }^{25}$

DESPITE ITS APPARENT FAILURES, Teamsters Local 383 had laid the groundwork for future success. Meanwhile, the members had come to realize that they would need outside help if they were to succeed in organizing Sioux City coal yards. At the same time, Teamsters in Minnesota had begun to implement plans to strengthen the union's position by expanding its base of support throughout the region. Sioux City Teamsters took the initiative in seeking the support of the resulting regional organization. ${ }^{26}$

24. Ibid., 16, 23 November 1939.

25. Ibid., 23 November 1939.

26. Plans to bring all over-the-road truck drivers under an area-wide agreement had been laid in the wake of the 1934 Minneapolis truck driver strikes 
In January 1937 the Minnesota Council of Teamsters invited representatives of the drivers unions in Minnesota, Wisconsin, and North Dakota to a meeting that resulted in the formal creation of the North Central District Drivers Council (NCDDC). At that initial meeting, the organizers decided to expand the tri-state council to include Iowa, South Dakota, and upper Michigan. ${ }^{27}$ Two of the organizers were sent to Sioux Falls, South Dakota, in response to a request for assistance from struggling General Drivers Local 749, which was trying to organize Sioux Falls drivers. After a few months in Sioux Falls with some organizing success, one of the NCDDC representatives, Shaun (Jack) Maloney, was sent to Sioux City. ${ }^{28}$

Maloney was a veteran of labor struggles. He had been a member of the Industrial Workers of the World (IWW) while working in North Dakota harvest fields in the late 1920s and early 1930s. When Minneapolis truck drivers struck in 1934, he played a leading role, and at various times he had served on the organizing staff of the Minneapolis drivers union. ${ }^{29}$

Maloney immediately felt at home in Sioux City. Howard Fouts, one of the officers of Local 383 and its full-time organizer, had a long background of involvement with the IWW movement; and Wallace Short, who probably never belonged to the IWW, was nevertheless well known for the support he

largely by Carl Skoglund and Vincent R. (Ray) Dunne, both of whom were members of the Communist League of America. See Erling N. Sannes, “'There is Power in a Union': Organizing Fargo's Milk-Wagon Drivers in 1934," North Dakota History 54 (Spring 1987), 5.

27. The representatives also chose the Northwest Organizer, a weekly paper published by the Minneapolis Joint Teamsters Council and edited by Miles Dunne, as the official newspaper of the newly formed council; and they elected Pat Corcoran, president of the Minneapolis Milk Drivers Union, Local 471, and Farrell Dobbs of the Minneapolis General Drivers Union, Local 544, as president and secretary-treasurer, respectively. Dobbs had been a leader in the Minneapolis truck driver strikes and had joined the Communist League of America a few months before it united with the American Workers' Party in December 1934 to form the Workers' Party of the United States. Farrell Dobbs, Teamster Rebellion (New York, 1972), 29-35; Northwest Organizer (Minneapolis), 14 January 1937.

28. See Erling N. Sannes, "'Union Makes Strength': Organizing Teamsters in South Dakota in the 1930's," South Dakota History (Spring/Summer 1988), 33-66.

29. Sannes, "'Union Makes Strength,'"; Farrell Dobbs, Teamster Politics (New York, 1975), 27-30. 
had given the movement during the 1915 free speech fight in Sioux City and again while he was mayor of Sioux City from 1918 to $1924 .{ }^{30}$

Soon after arriving in Sioux City in the fall of 1937, Maloney found Local 383 trying to negotiate a contract with the Coal Dealers Association. The union was in a state of disarray, and members were discouraged over their failure to get a strong foothold in the coal yards. Most of the members of the union were new to unionism and had little understanding of the class struggle; they did not know how to organize a grassroots democratic union. Maloney knew that such a union had to be directed and controlled by the members themselves if it were to be successful: He also knew that the struggle with the coal yards was lost, at least for the time being; the union's membership was dropping, and recruitment of new members was at a standstill.

Maloney established three immediate goals: to build support within the community, to try to convince the employers that the union was asking for nothing more than a chance to sit across the table and figure out a program for the members to work under, and, most important, to provide the membership with a cause they could all rally around. Maloney convinced Local 383's executive committee to adopt the slogan, "Make Sioux City a Good Place to Live." Eventually the slogan came to the attention of Wallace Short, who liked it so much that he adopted it as the motto of his labor paper, The Unionist and $P u b$ lic Forum. Short had an unusual and intense pride in Sioux City, and he was always on the alert for ways to improve the lot of its citizens, especially the farmers, working people, and small businessmen. After adopting the Teamsters slogan, he challenged others to do likewise. "If the rest of the folks don't take a hand," he wrote, "the Truck Drivers and The Unionist will soon be directing the destinies of Sioux City. ${ }^{31}$

THE ADOPTION OF THE SLOGAN, "Make Sioux City a Good Place to Live," ignited the faint spark of labor solidarity that existed within the struggling Teamsters union. Success

30. Cumberland, Wallace Short, 47-62.

31. Unionist and Public Forum, 22 June, 7 September, 12 October 1939. 
came first to other Sioux City unions, but the support shown by Teamsters Local 383 for the other unions revealed the benefits of labor solidarity and set in motion a sequence of events that eventually transformed the labor movement in Sioux City. The critical event was a seemingly minor confrontation involving the Cooks and Waiters Union, which was trying to organize ten cooks and waitresses at the Voss Cafe in Sioux City.

In the fall of 1937 the Cooks and Waiters Union and the Voss Cafe reached a verbal agreement that resulted in some improvement in wages and working conditions. But before a contract was signed the Sioux City Restaurant Association and the Iowa Restaurant Association learned of the impending agreement with the union and prevailed upon the owner of the Voss Cafe not to sign any agreement with the Cooks and Waiters Union or employ any of its members. When the eight workers who were members of the union refused to drop their union membership, they were all fired and replaced by other workers. $^{32}$

On November 29, 1937, Maloney enlisted the support of the Sioux City Trades and Labor Assembly, and along with a sizable contingent of members of the drivers union helped the dismissed workers set up pickets. Picketing continued until February 1938, when thirty-four picketers, including the president of the Sioux City Trades and Labor Assembly, several officers and members of the Cooks and Waiters Union, as well as Maloney and a number of Local 383 members, were all arrested on a complaint signed by the Voss Cafe, alleging illegal picketing and interference with business. A court order obtained from the Woodbury County District Court ordered the picketers to stop "walking up and down in front of the place," to "desist from the use of intimidating words ... and not to interfere with the conduct of the business at the cafe ${ }^{\prime \prime}$ or aid or abet any persons in the violation of the injunction. ${ }^{33}$

32. Ibid., 9, 16 December 1937.

33. U.S. Conciliation Service, RG 280, Case File 199/1678, Cooks and Waiters, Sioux City, Iowa, National Archives, Washington, DC; Jack Maloney, interview with author, 23 January 1988; Unionist and Public Forum, 10 February, 3 March 1938. 
The court order was one of the most sweeping labor injunctions ever granted up to that time in Sioux City. Nevertheless, Local 383 worked diligently with the Cooks and Waiters Union to enlist the support of labor in Sioux City to boycott the cafe. Business fell off, and eighteen months after the strike began, the cafe closed its doors. ${ }^{34}$

Even though the Voss Cafe strike was a failure for the cooks and waiters who had worked there, their union was inspired to continue organizing at other Sioux City cafes. Local 383, marching under the slogan, "Make Sioux City a Good Place to Live," emerged from the Voss Cafe controversy imbued with a sense of labor solidarity that had never existed in the union before. The drivers learned that by joining hands with other unions they could present a powerful force to those employers who refused to sit down and negotiate with them.

While the boycott of the Voss Cafe strike was under way, a local building contractor had begun hiring nonunion laborers on a Sioux City building project. The iron workers union and the teamsters union both had workers on the project. Maloney suggested that the teamsters and iron workers support the laborers in a strike to protest the hiring of nonunion laborers. Both groups agreed. ${ }^{35}$

The strike began on March 18, 1938. The three unions completely shut down the project. The next day the contractor agreed to hire only members of the laborers union. The laborers and iron workers withdrew their pickets, but Local 383 continued to picket the job when it was discovered that the contractor intended to reduce labor costs by employing laborers to do rod work-work that was clearly a function of the iron workers. ${ }^{36}$

The Sioux City Master Builders Association came to the defense of the contractor, and neither the contractor nor the Master Builders Association would negotiate with the iron workers and teamsters. The Sioux City Building and Trades Council requested the assistance of the United States Conciliation Service on March 21, but the Master Builders protested to

34. Ibid., 15 June 1939.

35. Jack Maloney, interview with author, 23 January 1988.

36. U.S. Conciliation Service, RG 280, Case File 199/1424, Master Builders Association, Sioux City, Iowa, National Archives, Washington, DC. 
Iowa's United States Congressman Vincent F. Harrington in a March 26 telegram, stating that "the Minnesota truck driving racketeers ... have attempted to organize a job" and that "Michael Sherman of the U.S. Conciliation Service was assisting them in starting trouble in Sioux City." The Conciliation Service informed Congressman Harrington that it had been in contact with the president of the Iowa State Federation of Labor, which believed that the attitude of the Master Builders Association was a reprisal for the part labor had played in the defeat of Gordon C. Hollar as public safety commissioner in the March 15 Sioux City primary election. ${ }^{37}$

During the few months Maloney had been in Sioux City it had become obvious to him that the mayor and other members of the city commission were hostile to labor, so he did not hesitate to act on Wallace Short's suggestion to organize and lead a movement within Local 383 to replace the mayor and the commissioner of public safety, the two most powerful offices under Sioux City's commission form of government. The movement spread quickly to other unions and to a majority of the unions affiliated with the Sioux City Trades and Labor Assembly. ${ }^{38}$

The unions supported David F. Loepp for mayor and Harold N. Sturgeon for commissioner of public safety. The incumbent mayor, W. D. Hayes, was running for a fifth term in 1938. Hayes was well liked and respected by the business community, and his reelection seemed almost certain. David Loepp was an attorney who had defended the members of Local 383 during the Voss Cafe injunction, and in 1936 he had run unsuccessfully for Woodbury County Attorney on the Farmer-Labor

37. Ibid.

38. Jack Maloney, interview with author, 13 February 1988; Joel Gatewood, Percy Langford, and John Skaff, longtime former members of Local 383, interview with author, 22 January 1988. Sioux City had been organized under the so-called Des Moines Plan since 1910. Under that commission form, the government of the city was divided into five departments: (1) public affairs (mayor), (2) finance and accounts, (3) public safety, (4) streets and public improvements, and (5) parks and public property. See Scott Alan Sorensen, "Law Enforcement During the 1930's," 4; John J. Hamilton, The Dethronement of the City Boss (New York, 1910), 15-71; Bradley Robert Rice, Progressive Cities: The Commission Government Movement in America, 19011920 (Austin, TX, 1977), 34-51; and Howard P. Chudacoff and Judith E. Smith, The Evolution of American Urban Society (Englewood Cliffs, NJ, 1988), 151-73. 
ticket. He conducted his campaign on a platform of a sound understanding of municipal affairs and a commitment to promoting fairness in relations between labor and industry. Harold Sturgeon, a printer by trade, was a past president and secretary of the Sioux City Trades and Labor Assembly, and had worked for Wallace Short as associate editor of the Unionist and Public Forum for a number of years. He had served on the Sioux City school board for four years before he resigned to run for commissioner of public safety. He was well known in lowa as an individual who had moved comfortably within the ranks of the socialists in the $1930 \mathrm{~s}^{39}$

The incumbents conducted a bitter, vicious, anti-labor campaign, while union members, under the direction and leadership of Local 383, held campaign rallies and went door-todoor throughout the city, talking with voters and distributing leaflets. Their hard work paid off when three labor-supported candidates were elected to the five-member city commission. In his election victory statement, the new mayor said, "I attribute a good deal to labor. . . I I feel it was a political error on the part of my opposition to attack labor." ${ }^{\text {40 }}$

The third labor-supported candidate, Milton C. Follis, a local contractor, defeated the incumbent commissioner of streets, who was seeking a fourth term. Follis had a long record of fairness toward labor unions, and his election was a severe blow to the Master Builders Association. After his election, Follis put pressure on the Master Builders to agree to negotiate with a committee from the iron workers and the teamsters. Shortly thereafter, Michael Sherman, the Conciliation Service agent who had been in Sioux City since shortly after the strike began, was finally able to get the Master Builders Association to negotiate with the striking unions, but only on condition that the teamsters remove their pickets. Loçal 383 refused to consider removing the pickets until an agreement had been reached. ${ }^{41}$

39. Sioux City Tribune, 26, 29 March 1938; Cumberland, Wallace Short, 130; Unionist and Public Forum, 31 March 1938.

40. Sioux City Tribune, 29 March 1938.

41. Ibid., 16 March 1938; Unionist and Public Forum, 31 March 1938; U.S.

Conciliation Service, RG 280, Case File 199/1424, Master Builders Associa- 
The final agreement, reached on April 6, 1938, covered not only the twenty workers employed by the contractor the three unions had struck on March 18, but at the insistence of Local 383 , the contract was expanded in the final negotiations to include the entire Sioux City building and trades industry. The rod workers, who were to have been paid a laborer's wage of fifty-six cents per hour, saw their wage almost doubled to one dollar per hour. Although only 150 laborers, iron workers, and teamsters were employed in construction at the time of the agreement, new workers were hired and old workers were recalled as the construction season got under way. Eventually, the contract included several hundred workers. ${ }^{42}$

The agreement was a significant victory for Sioux City construction workers and an important breakthrough for Local 383. For the first time it had a small but solid base in a major Sioux City industry. Prior to this contract there had been no written agreements between the workers and Sioux City contractors as to hours, wages, or conditions of employment. Moreover, it was the first time since 1919 that there had been a written contract between the building and trades unions and the Master Builders Association in Sioux City. The agreement was also a boon to the Sioux City Building and Trades Council. The organization of this council in October 1937 had been spearheaded by Teamsters Local 383 . The signing of the contract spurred several other Sioux City unions to join the council, although by the spring of 1938 only about half of the fourteen building and trades unions in Sioux City had joined. ${ }^{43}$

One other triumph for Local 383 came as a result of local workers' recognition of the need for regional solidarity. After Jack Maloney's arrival in Sioux City in the fall of 1937, Local

tion, Sioux City, Iowa, National Archives. Dennis Murphy, for more than twenty years a member of the Blacksmiths Union in the rails shops and who had served two terms as Parks Commissioner, easily won reelection to a third term. Sioux City Tribune, 16 March 1938; Unionist and Public Forum, 31 March 1938.

42. U.S. Conciliation Service, RG 280, Case File 199/1424, Master Builders Association, Sioux City, Iowa, National Archives; Unionist and Public Forum, 14 October 1937.

43. U.S. Conciliation Service, RG 280, Case File 170/448, Building Trades, Sioux City, Iowa, National Archives; Unionist and Public Forum, 14 October 1937. 
383 expanded its recruitment efforts to include over-the-road drivers, and in December 1937 joined the NCDDC. ${ }^{44}$ The NCDDC, however, soon faced a serious threat to its existence not from employers but from Daniel Tobin, president of the International Brotherhood of Teamsters (IBT).

Local 383 was among several area drivers locals that met in St. Paul, Minnesota, on January 13, 1938, to lay plans for an organizational drive to bring over-the-road drivers under an area contract. Tobin had viewed with alarm the growth and expansion of the NCDDC during its first year. He wanted no IBT organization broader than the Teamster Joint Councils, whose jurisdiction generally did not go beyond a particular city. When he heard about the organizing drive that was being planned in St. Paul, he sent a message to the gathering, informing the group that the IBT did not approve of general meetings between local unions; any conferences had to be confined to specific issues involving specific locals. In effect, Tobin ordered the NCDDC to disband. ${ }^{45}$

The outraged delegates unanimously elected a seven-man committee to go to Indianapolis to meet with Tobin and lodge a protest against his dictatorial policy. Tobin was shocked when the group explained the widespread rebellion that would develop if such a policy were to remain in effect. He reluctantly agreed to permit the formation of an area committee to develop a uniform contract for long-distance haulers. He did not permit the NCDDC the almost unlimited scope it sought, but his approval of an area-wide organizing campaign was a momentous event. ${ }^{46}$

On February 19-20, 1938, twenty-three delegates from twelve Teamsters locals met in Sioux City to begin organizing the North Central Area Negotiating Committee, which would coordinate the campaign to obtain uniform wages and working

44. Unionist and Public Forum, 23 December 1937.

45. Northwest Organizer, 13 January 1938; Farrell Dobbs, Teamster Power (New York, 1973), 169-87.

46. Northwest Organizer, 27 January 1938. The members of the committee who met with Tobin were Art Hudson, St. Paul Local 120; Carl Keul, Des Moines Local 90; Jack Maloney, Sioux City Local 383; Fred Smith, Duluth Local 346; Thomas V. Smith, Omaha Local 554; Jack Wirth, Fargo Local 116; and Farrell Dobbs, Minneapolis Local 544. 
conditions for all over-the-road drivers in the eleven north central states. The first test of the Area Committee's strength came when Holdcroft Transportation Company, a Sioux City interstate trucking firm, discharged four drivers who had joined Local 383. When Holdcroft refused the union's demands to reinstate the discharged workers and compensate them for lost time, the Area Committee called a strike, which was sanctioned by the IBT. On March 29, 1938, workers completely shut down Holdcroft operations at its Sioux City, Chicago, Marshalltown, Sioux Falls, Omaha, and Denver terminals. Forty-six hours after the strike began, the Sioux City Commercial Truckers Association asked for a meeting with Local 383 and quickly agreed to union demands for a seniority plan, as well as for reinstatement of the discharged drivers with pay for lost time. The agreement was a triumph for Local 383. Even though it did not provide for union recognition, it spurred recruitment of drivers into the union; it sent a clear message to employers throughout the area that they now had to contend with the IBT; and, even more important, it showed Daniel Tobin himself, perhaps for the first time, the power drivers could exert collectively working over a vast area to protect their jobs. ${ }^{47}$

THUS FORTIFIED by a newfound sense of solidarity with other workers in Sioux City and teamsters throughout the region, Teamsters Local 383 decided in the summer of 1938 that it was strong enough to launch a strike action of its own. In the fall of 1937 a small group of Sioux City bakery workers had come to Local 383 and asked for help in starting a bakery workers union. They applied for and received a charter as the Bakery and Confectionary Workers Union, Local 433 . Shortly after getting their charter, the bakery workers launched a joint campaign with Local 383 to recruit bakers and inside workers into Local 433 and bakery truck drivers into Local 383. By May 23, 1938, the two unions had a majority of all Sioux City bakery workers and drivers signed up as members, and they presented contracts to all of the Sioux City bakeries. ${ }^{48}$

47. Northwest Organizer, 24 February, 3 March, 7 April 1938.

48. Frank Santi interview, 10 August 1978, Iowa Labor History Oral Project, 
The negotiations resulted in an agreement on wages and working conditions, but on July 14, 1938, the Association of Bakery Operators informed the two unions that there was no use talking further if the unions were going to insist on a seniority plan and recognition of the two unions as sole bargaining agents for the workers. The sixty bakery truck drivers voted to strike; they were joined a few hours later by 112 bakers and inside workers. The strikers realized that without the protection of a strict seniority clause in the contract as well as recognition of the unions as sole bargaining agents for the workers they would have no job security. Other than a few small Sioux City bakeries that signed contracts with the two unions during the first days of the strike and continued to operate, the strike completely shut down the entire Sioux City baking industry. Metz Brothers Baking Company, one of the largest Sioux City bakeries, attempted to truck bread into Sioux City from their plants in Omaha, Nebraska, and Sioux Falls, South Dakota, but union pickets turned their trucks back before they could enter the city. ${ }^{49}$

The strike was still solid as the second week began. As bread supplies began to dwindle, however, the bakery owners aggravated the situation. They claimed that the two unions were disregarding the public interest by preventing bread supplies from reaching Sioux City. To counter these attempts to turn public sentiment against the strike, Local 383 distributed thousands of leaflets throughout the city calling attention to those Sioux City bakeries that had signed with the unions. The bakery drivers arranged to have a Minneapolis union bakery supply bread to Sioux City, but the Sioux City Bakery Owners Association prevailed upon that bakery not to make the delivery. Local 383 next moved to begin trucking bread into Sioux City from outlying Iowa towns and from bakeries that had signed with the unions. In addition, the union purchased as many as two thousand loaves of bread per day from a bakery in Akron, Iowa, that had signed a union contract, and sold them from its own store. ${ }^{50}$

Iowa Federation of Labor, AFL-CIO, State Historical Society of Iowa, Iowa City; Northwest Organizer, 28 July 1938.

49. Northwest Organizer, 28 July 1938.

50. Ibid. 
One of the bakeries-Metz-attempted to move bread using armed strikebreakers. The bakery charged that its trucks were being attacked and damaged by union pickets, but Local 383 was convinced that Metz had resorted to an old employer tactic of "hijacking" its own trucks in order to blame the union. The union filed a protest against such tactics with the La Follette Civil Liberties Committee of the United States Senate, charging that Metz's use of armed strikebreakers to move bread in interstate commerce violated federal law. ${ }^{51}$

At the beginning of the second week of the strike, the four largest bakeries-Continental Baking Company, Iowa Bakery, Metz Brothers Baking Company, and the Sioux City Bakerybought ads in the Sioux City newspapers containing the entire text of their proposal to the unions..$^{52}$ In a lengthy front-page editorial in the Unionist and Public Forum, Wallace Short condemned the bakery owners and urged the unions to reject the owners' proposal. Short charged that the clever, complicated legal language in the bakery owners' proposal would allow them to fire "every one of the workers who belongs to the union" because the existence of the union was "placed wholly in the will and wish of the owners." "A dispute of this sort does not stand by itself," Short wrote. He continued,

There is now a concerted drive throughout the country to destroy the labor organizations. On the side of the employers, the whole employer interests of the entire country are enlisted. The workers have no right to yield in a case like this, unless they are willing to betray the entire organized labor movement. The workers in every organization in the country are in honor bound to stand by any single organization that is fighting for its right to exist; just as the employers of the whole country who are against any labor organization DO stand together.

Short reminded workers that "the employers' effort was to swing public sentiment; that the employers have the money,

51. Ibid.

52. Sioux City Tribune, 25 July 1938. 
and usually the press; and that the workers have little except their own united loyalty. ${ }^{n 3}$

When the owners failed in their efforts to turn public sentiment against the strike or to break labor's solidarity, the owners resorted to another common strikebreaking method: sending stooges to union meetings to try to engineer a back-to-work movement. This effort had a fair amount of success. By the fourth week of the strike, the stooges had infiltrated the two unions and gained the support of forty-four workers, who signed a petition calling on Mayor Loepp for assistance in heading off the strike. The mayor was not impressed with the petition. In a sharply worded statement on August 8, Loepp said he "could see no reason why the employers should refuse to negotiate with the unions." 54

When the employers' plot to get the unions to back down came to light, those members of the two unions who had not signed the petition became more determined than ever not to yield. As the strike continued, fourteen of the workers who had signed the petition withdrew their names. The strike remained solid, but still the owners refused to negotiate with the unions. The Association of Employers of Sioux City, a counterpart of the well-known Minneapolis Citizens' Alliance which had fought for a generation to keep unions out of Minneapolis, pledged support to the Sioux City bakery owners. ${ }^{55}$

The Sioux City Trades and Labor Assembly gave its support to the strikers. It passed a resolution urging unions throughout the country to place Continental Bakery on the list of unfair employers, noting that Continental had signed agreements in many cities throughout the United States similar to the one proposed by the Sioux City unions. ${ }^{56}$

At the same time Local 383 filed a complaint with the National Labor Relations Board (NLRB) charging the Metz Brothers Baking Company with unfair labor practices. The

53. Unionist and Public Forum, 28 July 1938.

54. Sioux City Tribune, 9 August 1938.

55. Northwest Organizer, 28 July, 4 August 1938; Lois Quam and Peter J. Rachleff, 'Keeping Minneapolis an Open-Shop Town: The Citizens' Alliance in the 1930's," Minnesota History (Fall 1986), 105-17.

56. Unionist and Public Forum, 11 August 1938. 
complaint alleged that the owner, Henry Metz, had refused to allow his employees to join the union, but that he had instructed certain of his employees to join the union in an attempt to sabotage and break the union from within. The union claimed it had proof that Metz had incited his nonunion employees to attack union pickets and that Metz employees were hired and paid to carry out various strikebreaking activities. The complaint also quoted Metz as having said "that if any of the other employers affected by this strike sign an agreement, he would break them by placing a 5 -cent loaf of bread on the market." ${ }^{\prime 57}$

A few days later a representative of the NLRB arrived in Sioux City. With the assistance of Mayor Loepp he got assurance from the bakery owners that they would sit down to negotiate. But just before negotiations were to begin on August 11, the employers called for a postponement until the following week. To counter this stalling move, Local 383 sent a truck throughout the city bearing huge signs blaming the employers for stalling, and demanding immediate negotiations. Within twenty minutes after the truck was on the streets, an employers' representative withdrew their request for a delay and agreed to start negotiations immediately. By Saturday, August 13, the thirty-day strike had come to an end. ${ }^{58}$

The agreement included recognition of the two unions as sole bargaining agents for the workers, a seniority plan, a wage agreement, and other benefits. Wages for the bakery truck drivers were set at $\$ 32.50$ weekly plus 6 percent of all sales over three hundred dollars per week. The wage for special delivery truck drivers was set at thirty-five dollars per week. The bakers and inside workers received pay increases ranging from one dollar to four dollars per week. The contract also called for a forty-hour week, time and one-half for overtime, a one-week vacation with pay, full pay for weeks in which a holiday fell, and other benefits. ${ }^{59}$

The settlement was a complete victory for the two unions. It was the first union contract ever signed in the Sioux City bak-

57. Sioux City Tribune, 8 August 1938.

58. Northwest Organizer, 18 August 1938; Sioux City Tribune, 15 August 1938.

59. Northwest Organizer, 25 August 1938. 
ing industry, and for the first time in the history of Sioux City an entire industry had been organized under a closed shop contract that provided a seniority plan, uniform wages, working conditions, and other benefits for all workers in the industry ${ }^{60}$ Like the master builders strike a few months earlier, the bakery strike demonstrated the power of collective action. It also demonstrated to labor the value of a mayor such as David Loepp, who was willing to work tirelessly to bring about a settlement. The value of Public Safety Commissioner Harold Sturgeon was not lost on labor, either, when the police force was not unleashed as strikebreakers, as occurred so often elsewhere. The strike did not go the way the bakery owners thought it would. Instead of being just another lost strike, it culminated in a smashing triumph for unionism.

The success of the strike provided an incentive for other unions in Sioux City to step up their organizing efforts. In addition, bakery drivers elsewhere in Iowa began organizing. Less than six months after the strike was over, Local 383 met in Des Moines with fifteen bakery sections of Teamsters unions from Minnesota, Iowa, North Dakota, South Dakota, and Nebraska to organize an area conference that would plan a coordinated campaign for union recognition and a uniform contract on wages and working conditions for bakery truck drivers in the five-state area. ${ }^{61}$

As events unfolded in the months following the bakery strike, it proved to be the turning point for bringing lowa and Nebraska into the eleven-state over-the-road drivers agreement that had been negotiated by the North Central Area Negotiating Committee of the NCDDC in Chicago in August 1938.62 When that agreement was signed, Sioux City was one of only two major cities-the other being Omaha-in the entire eleven-state area that was not included in the agreement. After more than five years of struggle to organize drivers in Sioux City, the only victories Local 383 had achieved before the bakery strike settlement were the agreements a few months earlier

60. Ibid.

61. Northwest Organizer, 16 February 1939.

62. Farrell Dobbs, Teamster Power, 177-87; Unionist and Public Forum, 9 November 1939. 
with the Sioux City Master Builders Association and with Holdcroft Transportation; and those agreements, significant as they were, affected only a small number of drivers. Before the bakery strike was settled, Local 383 was not much more than a paper union that had been beaten back time after time by Sioux City's recalcitrant employers; its members had begun to feel desperate and helpless. After the strike was over it was clear to union members that they had played an important part in making Sioux City a good place to live.

LOCAL 383 soon found that the victory it had achieved in the bakery strike was short-lived. The strike had provided solidarity among the drivers, but it had also strengthened the various business associations in Sioux City for even greater conflicts to come. A new phase of Teamsters organizing began in September 1938 and involved a long, bitter, six-month lockout of the over-the-road drivers, the unsuccessful attempt by several members of the business community to recall Mayor Loepp and Harold Sturgeon, a bitter coal drivers strike, and the support by the Sioux City Business Men's Association of the role the federal government played in breaking the unions, all of which awaits further research. In the wake of these conflicts Local 383 emerged by 1940 as a strong militant drivers union with twelve hundred members. ${ }^{63}$

The union's experience in the 1930s had laid the groundwork for its emergence as a strong union. In those years it had learned to cope with shifting legislation and the tactics of Sioux City businessmen and industrialists. It had become part of a regional network of workers who lent support to each other's organizing efforts. It had begun to master the art of cultivating community support. It had come to appreciate the value of cooperation with workers in other trades. Most important, its members had gained a consciousness of their own strength through solidarity.

63. MSS 9 Teamsters, series 1 , box 29 . 
Copyright of Annals of Iowa is the property of State of Iowa, by \& through the State Historical Society of Iowa and its content may not be copied or emailed to multiple sites or posted to a listserv without the copyright holder's express written permission. However, users may print, download, or email articles for individual use. 